\title{
Sakizaya or Amis? -- A Hidden Ethnic Group in Taiwan?
}

\author{
Melissa Shih-hui Lin \\ Department of Indigenous Languages and Communication \\ National DongHwa University \\ No.1, Sec 2, Da Hsueh Rd, Shoufeng, Hualien 97401, Taiwan \\ Tel: 886-3-863-5835Ｅ-mail: linshihhui@mail.ndhu.edu.tw
}

\begin{abstract}
1. Sakizaya dialect

2. Northern dialect (Nansi Amis)

3. TavaLong-Vataan dialect

4. Central dialect (Coastal and other Soukuzun Amis)

5. Southern Amis (Puyuma Amis and Hanchan Amis)
\end{abstract}

Amis, one of the Austronesian languages, is spoken by the largest indigenous minority on the island of Taiwan. The population is estimated to be 140,000 . The Amis language is spoken mainly in Hualien and Taitung, the eastern part of Taiwan. In 1990s, a Japanese linguist Tsuchida (1989) provided a set of categorization for the Amis language:

From the categorization above, Sakizaya belonged to a subcategory of Amis. At the same time, this categorization also reflected that from the "Takobowan Incident" in 1878 the exiled Sakizaya, in order to escape the ethnic cleansing by Qing government, living among the Amis, were simply a subgroup of the larger ethnic group, and so Sakizaya were classified as Amis from then on. The Sakizaya, as a distinct ethnic group, officially did not exist.

However, not only historical materials show the term Sakizaya were known to the Spanish and to the Dutch East India Company during the 17th century (Hsu, Liao and $\mathrm{Wu}, 2001$ ), but also the language data collected in this paper show there are differences between Sakizaya and Amis. (Both Nansi Amis and Sakizaya are spoken mainly in northern Hualien. This paper will further make examples of the phonological, morphological and syntactic differences between Sakizaya and Nansi Amis.) However, it is still difficult to define whether Sakizaya is not a dialect of Amis, but a language.

In January of 2007, Sakizaya was officially recognized as Taiwan's $13^{\text {th }}$ Indigenous Group in Taiwan and one of the most important claims used by the Sakizaya elites in the process of ethnic reconstruction was the language. It seems to me that this ethnic reconstruction is motivated rather by the current Taiwan political environment than the ethnic group itself. It follows that it may occur that the language has been only an instrument to achieve political ends, but - no matter whether true or not - a much more in-depth study is still necessary to determine the status of the language and its relation to other languages, such as Amis, to make a final judgment on the whole process of ethnic reconstruction Sakizaya case.

Keywords: Sakizaya, Amis, Language description, Language \& dialect, Ethnic identity

\section{Introduction}

In January of 2007 , Sakizaya was recognized by the Taiwan government as the $13^{\text {th }}$ Indigenous Group in Taiwan. However, for decades, Sakizaya was considered as only a subgroup of Amis, the largest Taiwan Indigenous group. Language is one of the most important claims used by the Sakizaya people, especially the elites, in the process of "ethnic reconstruction" (Please see Note 1). They believe Sakizaya is at least $60 \%$ different compared with the Amis in the linguistic point of view. However, because of the lack of the related linguistic studies, there are still a lot of debates concerning about the status of Sakizaya, no matter about its ethnic status or its language status. Some people even consider the Sakizaya recognization by the Taiwan government as a political show, instead of the real ethnic reconstruction. 
In order to extinguish these debates, it is necessary to have a much more in-depth study to determine the status of the Sakizaya language and its relation to other languages, such as Amis, to make a final judgment on the whole process of ethnic reconstruction - Sakizaya case.

This study, first, is going to introduce the Austronesian languages in Taiwan, mainly the historical background and the language-or-dialect question about the Austronesian languages status in Taiwan. This study will also make more discussion about whether the language-or-dialect question has the effect on the ethnic and linguistic identity of Taiwan indigenous peoples. Second, this study will focus on the historical records of Sakizaya; at the same time tries to compare the Amis and the Sakizaya linguistically, i.e. phonologically, morphologically and syntactically. At the end, according to the Sakizaya case, this study will discuss the importance of the language in the building of the ethnic identity.

\section{Austronesian languages in Taiwan}

Taiwan indigenous people currently comprise $2 \%$ of the total around 21 million population in Taiwan. However, almost all of the Austronesian languages spoken by the Taiwan indigenous people are facing the danger of becoming extinct.

Recent research suggests the Taiwan indigenous people may have been living on the island at least before Han Chinese immigration began in the $17^{\text {th }}$ century. (Blust 1999) During the Qing Dynasty (1644-1911), these Taiwan indigenous people were named either "Plains tribes" 平埔族 or "High Mountain tribes" 高山族. The former term was used to define the people who had pledged their allegiance through their payment of a head tax, and the later was used to define the people who had not submitted to Qing. During the following Japanese colonial period (1895-1945), the Japanese anthropologists maintained the binary classification of the Taiwan indigenous people, and created a category of recognized tribes from the "High Mountain tribes", including Atayal, Bunun, Tsou, Saisiat, Paiwan, Puyuma, Amis, Yami and Thao. After 1945, the Kuomintang government used "mountain compatriots" 山地人 to call all the Taiwan indigenous people, instead of following Japanese classification. Until 1988, the period of President Chiang Ching-kuo ends, and the activities oriented by the Taiwan indigenous people themselves started. During the period of following President Lee Teng-hui, the government started to use the term “Indigenous Peoples" 原住民 to name the Taiwan indigenous people and the government adopted the Japanese classification.

Until 2007 there are thirteen Taiwan indigenous peoples which are recognized by the government. According to the March 2004 statistics of the Council of Indigenous Peoples (Please see Note 2), the populations of these Taiwan indigenous peoples are as follows: Atayal $(91,208)$, Saisiyat $(5,445)$, Bunun $(44,028)$, Tsou $(5,740)$, Rukai $(10,966)$, Paiwan (74,093), Puyuma (9,432), Amis (159,190), Yami (3,295), Thao (506), Kavalan (503), Truku (131), and Sakizaya (unknown).

Nine of the Taiwan indigenous peoples were originally recognized prior to 1945 by the Japanese government, and the later five were recognized by the government after 2000. The Thao was recognized on September 22, 2001. The Kavalan was recognized on December 25, 2002. The Truku was recognized on January 14, 2004. The Sakizaya was recognized on January 17, 2007. There are still other indigenous peoples in Taiwan, however they have not been officially recognized yet. These indigenous peoples include Ketagalan, Luilang, Taokas, Papora, Babuza, Hoanya, Pazeh and Siraya.

As mentioned above, almost all of the Taiwan indigenous languages are facing the danger of becoming extinct. In this context, the language planning work becomes very important. According to the current language policy in Taiwan, once the tribes are recognized by the government, their languages will be taught in schools, at least to encourage pupils in elementary school and students in junior high school to learn a native language. As a result, the language corpus planning work will be followed, including the language textbooks, dictionaries and so on. (Huang 2004) Before, there are very few indigenous language textbooks, as most textbooks were prepared by nonprofessionals. Moreover, there are few well-trained language teachers. Once the tribes are recognized by the government, their languages status will be confirmed and then the language policy of the government can help revitalize the languages; in another word, to confirm the language status can also help unite the ethnic identity of the tribes. However, it must be very careful to confirm the language status. Without the related linguistic proof, the language-or-dialect question might become an instrument to achieve political ends. The Sakizaya case can be one example: one of the most important claims used by the Sakizaya elites in the process of ethnic reconstruction was the language, although their "language" was treated as one of Amis dialects for decades, on which this study will make more discussion in the following section.

\section{Historical Background of Sakizaya}

According to my field work (2007), some informants believe the Siraya, one of the extinct Taiwan indigenous groups, was the ancestor of the Sakizaya. Around 1621, Siraya, who were attacked by one general in Ming Dynasty from Mainland China, were forced to move from Tainan, the western part of Taiwan to the eastern part of Taiwan, where was believed to be the Sakizaya original tribe. However, because of no written records or documents to support this idea, this saying still needs to be proved. 
In $17^{\text {th }}$ century, the term "Sakizaya" was first used in the literary records left by the Spanish and the Dutch, who colonized Taiwan during that period. In 1630's, during the Spanish period and the following period of the Dutch East India Company, names of tribes and names related to places with mineral deposits (esp. gold) in the eastern part of Taiwan were mentioned. Among these place and tribe names, some are believed to be of Sakizaya tribes, such as pazik, nararacanan and etc.

The following map (figure 1.) shows the distribution of old Amis tribes and Sakizaya tribes. Kalingko is the Amis name of the current Hualien City. From the map, it is clear that the Sakizaya tribe nararacanan was living among the Nansi Amis tribes before. (i.e. Nansi Amis is one subgroup of Amis.)

In 1640, Pieter Boon, a Dutch soldier on his expedition to the eastern part of Taiwan, described in his records the Sakizaya people living there. Again, the term "Sakizaya" was mentioned. According to my field work results (2007), it can be only assumed that, for a long time, Sakizaya had stayed on Qilai plains of the eastern Taiwan, close to where is now Hualien City.

During 1800s, indigenous peoples often fought with Qing soldiers from Mainland China to protect their territory around Qilai plains. In 1878, the Kavalan people of Kaliyawan area allied with the Sakizaya to attack Qing, known in the history as the "Kaliyawan Incident". (Note 3) On the other hand, because among the Sakizaya people, it was only the Takobowan tribe which took part in this Incident, so this Incident is also called the "Takobowan Incident".

After the "Kaliyawan Incident" or "Takobowan Incident", the Sakizaya and the Kavalan people were forced to disperse to other places. For the Sakizaya, they started to hide among the Amis in order to survive. (Hsu, Liao and Wu 2001)

During the later Japanese colonial period, from 1895 to 1945, Sakizaya was mentioned again (Mabuchi 1935 : 33) : "Sakizaya was called by the Amis as Sakiraya, and by the Kavalan as Sakizaya... The people who stayed at Cipawkan tribe called themselves as Sakizaya. The people who stayed at Sakol tribe called themselves as Sakidaya..." However, in this text Sakizaya was considered as part of Amis.

In 1990s, the Japanese linguist Tsuchida (1989) even provided a set of categorization for the Amis language:

1. Sakizaya dialect

2. Northern dialect (Nansi Amis)

3. TavaLong-Vataan dialect

4. Central dialect (Coastal and other Soukuzun Amis)

5. Southern Amis (Puyuma Amis and Hanchan Amis)

It was very clear that the Sakizaya was considered as a dialect of Amis language.

From 1990's on, the Sakizaya elites have strived for the ethnic recognition by the government. One of their claims in the process of the ethnic reconstruction was their language, which was used as a marker of their ethnicity. In January of 2007, Sakizaya was recognized by the Taiwan government as the $13^{\text {th }}$ Indigenous Group in Taiwan.

\section{The current distribution of Sakizaya}

According to my field work (2007), the current distribution of Sakizaya is very dispersive compared with the other Taiwan indigenous groups. The reason to cause the Sakizaya population now so dispersed is assumed the historical event. As mentioned in the previous section, after the "Kaliyawan Incident" or "Takobowan Incident" in 1878, the Sakizaya people were forced to disperse to other places and started to hide among the Amis in order to survive. However, the most Sakizaya tribes currently are located in the Hualien County.

Hualien, the eastern part of Taiwan, is characterized by its population diversity. While the indigenous peoples only account for about $2 \%$ in Taiwan's 23 million populations, they form almost a quarter of total population in Hualien. The geographical distribution of the indigenous peoples is as followed: Taroko in the north and middle parts of the county, Amis in the middle-to-north and the coastal area, and Bunun in the middle and south. Besides of the mentioned three main indigenous peoples, there are still Kavalan and Sakizaya dispersing in Hualien.

In the map (figure 2.), the left map shows the Taiwan Island and the right one shows the Hualien County. The white circles in the left map show the current distribution of the current Sakizaya, though the population of each tribe is very small.

In the table 1., this study tries to list the estimated number of Sakizaya population in seven main tribes in Hualien County. This result is mainly based on the questionnaire about the lexicon difference between Amis and Sakizaya. (This study will discuss the lexicon difference between Amis and Sakizaya in the following section.)

From the table above, the estimated current number of Sakizaya population is assumed to be less than 2000. Also, according to the field work, most of them are elders. 
In the map (figure 3.), it shows both the distribution of Amis and Sakizaya. The yellow, orange, blue, green and pink parts show the distribution of the main Amis dialects. The black circles show the distribution of Sakizaya. From this map, it is clear that the Sakizaya people are living among the Amis.

As a short conclusion, since the current distribution of Sakizaya people are so dispersed, it is not easy to unite the whole tribes and further to reconstruct the ethnic identity. From 1990s the Sakizaya elites keep making demands that other accept their self-recognition; however the most difficult part is to communicate with their own people. As mentioned, the Sakizaya people are living among the Amis for a long time. They become mixed in the way of living habits and so on. The Sakizaya people even lost their own traditional ceremonies and costumes, which they later try to reconstruct during the process of the self-recognition. The only difference between the Amis and the Sakizaya people is the languages. That is also the reason why the language is one of the most important claims in the process of the ethnic reconstruction by the Sakizaya elites. In the following section, this study will try to compare Amis and Sakizaya linguistically.

\section{Some Linguistic Differences between Amis and Sakizaya}

The data on the linguistic research of Sakizaya are comparatively scarce, which include the researches of Mabuchi, $\mathrm{T}$. (1935), Tsuchida, S. (1982, 2002), Jen-Kuei Li (1999) and Tsukida, N. (1993). The previous three only mentioned Sakizaya on the categorizing of Amis language, but Tsuchida labored over a 39-paged specific discourse on Sakizaya language. Besides, the Sakizaya people's spiritual leader, principal Lai-Won Lee (1996), also contributed greatly to related discourses. In the following, this study will try to compare Sakizaya and Amis (mainly Nansi Amis) within the viewpoint of linguistics.

\subsection{Phonetic/Phonological difference}

According to my field work (2007), first Sakizaya language has two more consonants than Amis: /z/, /b/. Second, the consonant /f/ in Sakizaya language is seldom employed. And the most distinguished part in phonetics is that Amis' $/ \Lambda /$ and $/ \mathrm{x} /$ are mostly replaced by $/ \mathrm{h} /$ in Sakizaya. However, it is still unknown whether the phonetic differences are caused by the mutually language contact nowadays, it is still worthy to pay attention on.

Phonologically, in Sakizaya when /ng/ appears in front of /c/, it will become /n/, but in Amis it will remain as /ng/. For example:

$\begin{array}{llll}\text { Nansi Amis } & & \text { Sakizaya } & \\ \text { bangcal } & \rightarrow & \text { bancal "pretty" } \\ \text { pangcah } & \rightarrow & \text { pancah "(tribe name)" }\end{array}$

On the other hand, there are some phonological rules which will occur in Sakizaya, but not in Amis. For example:

$\begin{array}{lll}\text { Nansi Amis } & \text { Sakizaya } & \\ \text { sapaorip } & \text { sipaozip "to make it alive" } \\ \text { sipakasoy } & \text { sapakasoy "to cut firewood for other people" }\end{array}$

\subsection{Lexical difference}

According to the field work (2007), there is lexical difference between Sakizaya and Nansi Amis. However, the number of the lexicon which have been found can differentiate Sakizaya and Nansi Amis are not a lot. (Please see table 2.) Concerning this part, it is worthy to have much more research, because the lexical difference would be the key point to decide whether Sakizaya is a dialect of Amis and to clarify the relation between Sakizaya and Amis language.

\subsection{Morpho-syntactic difference}

In the previous related papers, only Tsukida (1993) stated both the Sakizaya and Amis languages have a verbal prefix $m i$ - which functions as subjective focus (or actor voice) and verbal prefix ma- as subjective or objective focuses. However, the Sakizaya language has one more prefix mo- than Amis, but Sakizaya doesn't have verbal infix -om- as subjective focus in Amis.

In the following, this study will introduce the voice system and the case marker system of Sakizaya which have been found in the field work. On the other hand, this study will also compare what have been found with the Amis voice system and the Amis case marker system proposed by $\mathrm{Wu}(2006)$.

In the voice system, Sakizaya seems to have two more prefixes: $a$ - and $\varnothing$ - which function as actor voice marker than Amis. Besides, Sakizaya does not have infix $-u m$ - as actor voice marker, but prefix mo-. For the undergoer voice marker, Amis seems to have one more circumfix mi-...-an. There is no difference in the instrument voice marker and locative voice marker between Sakizaya and Amis. (Please see table 3. and 4.)

In the case marker system, according to the field work the case markers for the personal proper singular and plural 
nouns are the same, however, this point needs more investigation. From the tables below, there is locative case marker in Sakizaya, but in Amis the locative case marker is absent. (Please see table 5. and 6.) Here, please note that Amis $u$ is pronounced as $/ 0 /$.

Besides of the voice system and the case marker system, there is also difference in the expression of the 3rd singular and plural pronouns between Sakizaya and Amis. Please see the table 7.

According to the field work, most of the sentence patterns are the same between Sakizaya and Amis. Only the negative imperative sentence pattern between Sakizaya and Amis is different, shown as below:

Nansi Amis
aka pi-/aka ka- $\quad$ Sakizaya
amana pi-/ amana ka-

For examples (Note 4):

Nansi Amis

aka pi-sabana' ci taymo-an.

NEG [IMP-to cheat] [OBL Taymo-OBL]

"Don't cheat Taymo!"

aka ka--sabana' no tao kiso.

NEG[KA-to cheat] GENothers [2SG.NOM]

"Don't' be cheated!"
Sakizaya

amana pi-sabana' ci taymo-an.
NEG [IMP-to cheat] [OBL Taymo-OBL]
"Don't cheat Taymo!"

amana ka-sabana' no tao kiso.

NEG [KA-to cheat] GEN others [2SG.NOM]

"Don't' be cheated!"

From the mentioned differences in phonology, lexicon and morpho-syntax between Amis and Sakizaya, it is still not clear whether Sakizaya can be defined as a language, instead of a dialect of Amis. One of the reasons can be the Sakizaya people have been living among the Amis for a long time. Their languages are already mixed in some way. In the field work, there are many informants who even cannot differentiate the language they are using is Sakizaya or Amis. As a result, before to compare Sakizaya and Amis, it seems necessary to "reconstruct" the Sakizaya language itself.

As mentioned before, from 1990's on, the Sakizaya elites have strived for the ethnic recognition by the government. One of their claims in the process of the ethnic reconstruction was their language. However, if the main claim in the process of the ethnic reconstruction was the language, and the language itself needs to be reconstructed in some level, it must be very careful to make a final judgemen on the whole process of the ethnic reconstruction. On the other hand, the related research on Sakizaya is getting more important.

\section{Conclusion}

Language is one of the most important building blocks of ethnic identity and can be a marker of identity. (Safran, 2008) However, when one group of people is trying to use language as a main claim in the process of building the ethnic identity, they shall be very careful. Otherwise, there would be some worries that language is used as an instrument of ethnicity building. (Jusdanis 2001: 120f.)

From the discussion in this paper, obviously there are some linguistic differences between Amis and Sakizaya. However, whether these differences are enough to decide Sakizaya is an independent language, instead of a dialect or a variation of Amis? On the other hand, how to define a dialect and a language clearly? Or is it necessary to define Sakizaya is a not dialect of Amis in the process of the Sakizaya ethnic reconstruction?

According to the current language policy of Taiwan government, once the tribe is recognized by the government, the language status will be confirmed and the language planning work follows. After 2007, when the Sakizaya people was recognized by the government, there appeared Sakizaya textbooks for the pupils in the elementary schools and the students in the junior high schools. The Sakizaya language also became part of indigenous special admissions to universities. It seems to me because of the process of the self-recognition, the Sakizaya people indeed revitalize their own language in some way, although most of them have seldom used their own language in their daily lives, instead of using Mandarin or Amis.

This study agrees that language can be a marker of ethnicity, but not necessary. According to Chambers and Trudgill (1998), "a language is a collection of mutually intelligible dialects". Danish and Swedish are mutually intelligible, but usually they are considered to be different languages. It might be better to say Danish is less than a language, according to Chambers and Trudgill. However, the status of Danish will not bring any influence on its nation-building, because there are still other elements to solidify this ethnic group, such as its culture and so on.

In the Sakizaya case, language is the most important claim of Sakizaya elites in the process of its ethnic recognization. As mentioned, most of their traditions are lost because they have been living among Amis for decades. So it is 
necessary to have a much more in-depth linguistic study in Sakizaya. Through the linguistic study, it might help people to know more about this endangered indigenous people in Taiwan and at the same time help to reconstruct the ethnic identity of the Sakizaya people.

\section{References}

(In English)

Blundell, David (ed). (2000) Austronesian Taiwan, Linguistics, History, Ethnology and Prehistory. Phoebe A. Hearst Museum of Anthropology, University of California, Berkeley with Shung Ye Museum of Formosan Aborigines.

Blust, Robert. (1999). Subgrouping, circularity and extinction: some issues in Austronesian comparative linguistics. Selected papers from the Eighth International Conference on Austronesian Linguistics, ed. by Elizabeth Zeitoun \& Paul Jen-kuei Li, pp. 31-94. Taipei: Institute of Linguistics, Academia Sinica.

Chambers, J.K. and Petr Trudgill. (1998). Dialectology (2nd edition). Cambridge University Press.

Chen, Yi-fong and Lin, Shih-hui. (2008). Language, Place and Identity: The Politics of Place and Language in the Formation of Indigenous Identity in Hualien, Taiwan. 2008 IGU, Tunisia.

Huang, Lillian M. (2004). The preservation and the promotion of aboriginal languages in Taiwan. Paper read at 2004 North American Taiwan Studies Conference, June 17-20, 2004. Hawaii: University of Hawaii at Manoa.

Jusdanis, Gregory. (2001). The Necessary Nation. Princeton: Princeton University Press.

Safran, William. (2008). Language, ethnicity and religion: a complex and persistent linkage. In Nations and Nationalism 14 (1), pp.171-190. Blackwell.

Spencer, Andrew. (1991). Morphological Theory. Blackwell.

Stewart, T. W. and Vaillette, N. (2001). Language Files - Materials for an Introduction to Language \& Linguistics (8th edition). The Ohio State University Press.

Tsukida, Naomi. (1993). A Brief Sketch of the Sakizaya Dialect of Amis. Tokyo University Linguistic Paper 13. pp.372-413.

Tsuchida, Shigeru. (1982). Subclassification of Amis dialects. Unpublished MS.

Tsuchida, Shigeru. (1983). Austronesian languages in Taiwan (Formosa). In S. A. Wurm and Shiro Hattori(eds). Language Atlas of the Pacific Area. Canberra: Australian National University.

Wu, Joy. (2006). Verb Classification, Case marking, and Grammatical Relations in Amis. The Ph.D. dissertation. The State University of New York at Buffalo.

(In Chinese)

Li, Paul Jen-Kuei (李壬癸). (1999). Taiwan yuanzhumin shi - yuyan pian 臺灣原住民史 - 語言篇 (The linguistic history of Formosan aborigines) Nantou. Taiwan: The Historical Research Commision of Taiwan Province 台 灣省文獻委員會.

Lin, Shih-hui (林蒔慧). (2007). Saqilaiyayu chutan 撒奇萊雅語初探 (Some Investigation on Sakizaya). NSC95-2411-H-259-006 Reports.

Sing 'Olam (星・歐拉姆). (2005). Ameiyuwen sucheng duben 阿美語文速成讀本 (The Amis Reader). Taiwan zuqun muyu tuixing weiyuanhui 台灣族群母語推行委員會.

Notes

Note 1. For decades, the Sakizaya has lost their traditional garments and also the yearly ceremonies. The elites are trying to reconstruct all the tradition according to the oral description from the elders during these years. It seems for the Sakizaya people the only existed evidence to prove they are an independent ethnic group is their own language.

Note 2. The March 2004 statistics of the Council of Indigenous Peoples, Executive Yuan, Taiwan, R.O.C. (http://www.apc.gov.tw/en/statistic/number2.aspx)

Note 3. Kavalan is one of Taiwan indigenous people, who originally inhabited current Yilan County, the north-eastern Taiwan. Most of them moved to the coastal area of Hualien and Taitung in the $19^{\text {th }}$ century.

Note 4.

NEG: negation

IMP: imperative

NOM: nominative

GEN: genitive

OBL: oblique 
Table 1. The estimated number of Sakizaya population in main seven tribes. (Chen 2005; Lin 2007)

\begin{tabular}{|c|c|c|c|}
\hline Tribe & Total population & $\begin{array}{c}\text { The number of Taiwan } \\
\text { indigenous people }\end{array}$ & $\begin{array}{c}\text { The number of Sakizaya } \\
\text { people }\end{array}$ \\
\hline hopo' & 6,000 & 1,500 & 400 \\
\hline copo' & 1,714 & 578 & 440 \\
\hline apalo & 780 & 554 & 378 \\
\hline ciwidiyan & 1,260 & 630 & 32 \\
\hline cilakayan & 832 & 478 & 44 \\
\hline karorowan & 493 & 445 & 292 \\
\hline maibol & 400 & 360 & \\
\hline
\end{tabular}

Table 2. (Lin 2007)

\begin{tabular}{|l||l|l|}
\hline Lexical meaning & Sakizaya & Nansi Amis \\
\hline \hline Ox & katararan & rarapa/gulung \\
\hline Chicken & tolako & 'ayam \\
\hline Snake & bao & 'oner \\
\hline Clothes & zigoc & fodoy \\
\hline Girl & tataina & fafahi/fafahiyan \\
\hline Senior & babalaki & mato'asay \\
\hline Priest & mapalaway sikawasay \\
\hline Nose & cihek & ngoso' \\
\hline Tooth & ngipen & wadis \\
\hline Language & kamu & sowal \\
\hline & & daedace \\
\hline
\end{tabular}

Table 3. The estimated Sakizaya Voice system (Lin 2007)

\begin{tabular}{|l|l|}
\hline \multirow{2}{*}{ Actor Voice Marker } & $a-$ \\
\cline { 2 - 2 } & $m i-$ \\
\cline { 2 - 2 } & $m a-$ \\
\cline { 2 - 2 } & $m o-$ \\
\cline { 2 - 2 } & $O-$ \\
\hline Undergoer Voice Marker & $m a-$ \\
& $-e n$ \\
\hline Instrument Voice Marker & $s a-$ \\
\hline Locative Voice Marker & $-a n$ \\
\hline
\end{tabular}

Table 4. The Amis Voice system (Wu 2006)

\begin{tabular}{|c|c|c|c|}
\hline Actor Voice (AV) Markers & $m i-$ & $-u m-$ & $m a-$ \\
\hline \multirow[t]{3}{*}{ Undergoer Voice (UV) Markers } & $m a-$ & $\begin{array}{l}m a- \\
m a-\ldots-u m-*\end{array}$ & $m a-k a-{ }^{*}{ }^{43}$ \\
\hline & \multicolumn{2}{|l|}{$m i-\ldots$-an } & $k a-\ldots-a n$ \\
\hline & \multicolumn{2}{|l|}{-en } & $\begin{array}{l}-e n \\
k a-\ldots-e n\end{array}$ \\
\hline $\begin{array}{l}\text { Instrument Voice (InV) Markers } \\
\text { (the bold-faced part) }\end{array}$ & sa-pi- & sa-ka-...-um- & sa-ka- \\
\hline $\begin{array}{l}\text { Locative Voice (LV) Markers } \\
\text { (the bold-faced part) }\end{array}$ & $p i-\ldots-a n$ & $k a-\ldots-u m-\ldots-a n$ & $k a-\ldots-a n$ \\
\hline
\end{tabular}


Table 5. The estimated Sakizaya Case Marker system (Lin 2007)

\begin{tabular}{|c|c|c|c|c|}
\hline \multirow{2}{*}{ Nouns } & \multicolumn{4}{|c|}{ Case markers } \\
\cline { 2 - 5 } & Nomonativa & Genitive & Oblique & Locative \\
\hline Common & $k o$ & $n o$ & to & $i \ldots$ (an) \\
\hline Personal Proper & $c i$ & $n i$ & $c i \ldots a n$ & $c i \ldots a n$ \\
\hline
\end{tabular}

Table 6. The Amis Case Marker system (Wu 2006)

\begin{tabular}{|l|l|l|l|l|}
\hline \multirow{2}{*}{ Nouns } & Nominative & Genitive & Dative \\
\hline Common & $k-u$ & $n-u$ & $t-u$ \\
\hline \multirow{2}{*}{ Personal Proper } & Singular & $\varnothing-c i$ & $n-i$ & $c i \ldots$-an \\
\cline { 2 - 5 } & Plural & $\varnothing-c a$ & $n-a$ & $c i \ldots$-an \\
\hline
\end{tabular}

Table 7. The expression of the 3rd singular and plural pronouns in Sakizaya and Amis (Lin 2007)

\begin{tabular}{|l|l||l|l|l|}
\hline $\begin{array}{l}\text { Personal } \\
\text { Pronoun }\end{array}$ & Language & Nominative & Oblique & Genitive \\
\hline \hline 3 SG & Sakizaya & ciniza & cinizaan & iza \\
\cline { 2 - 5 } & Amis & cinga & cingraan & ira \\
\hline \multirow{3}{*}{$3 \mathrm{PL}$} & Sakizaya & koheni & tohenian & heni \\
\cline { 2 - 5 } & Amis & cangra & cangraanan & nangra \\
\hline
\end{tabular}

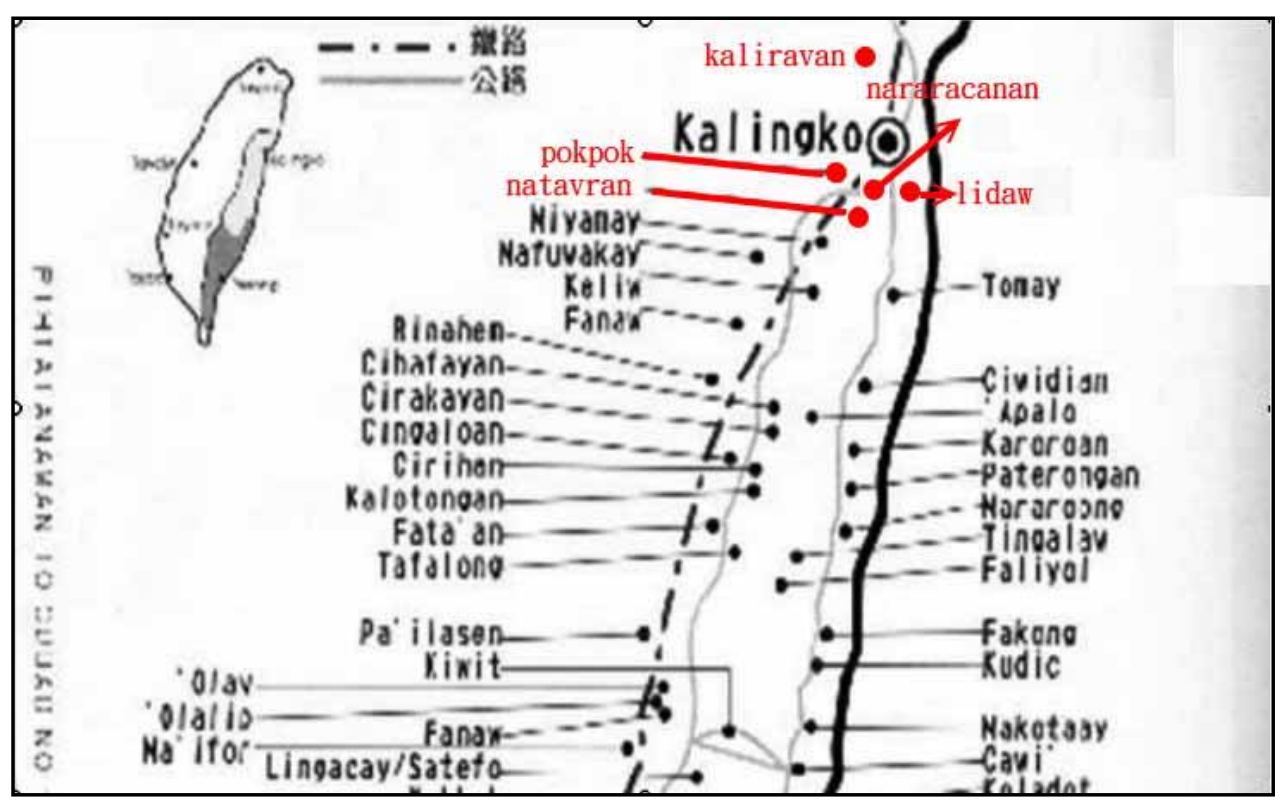

Figure 1. The distribution of the old tribes of Nansi Amis and Sakizaya in Hualien (Sing 'Olam 2005;

Lin 2007) 


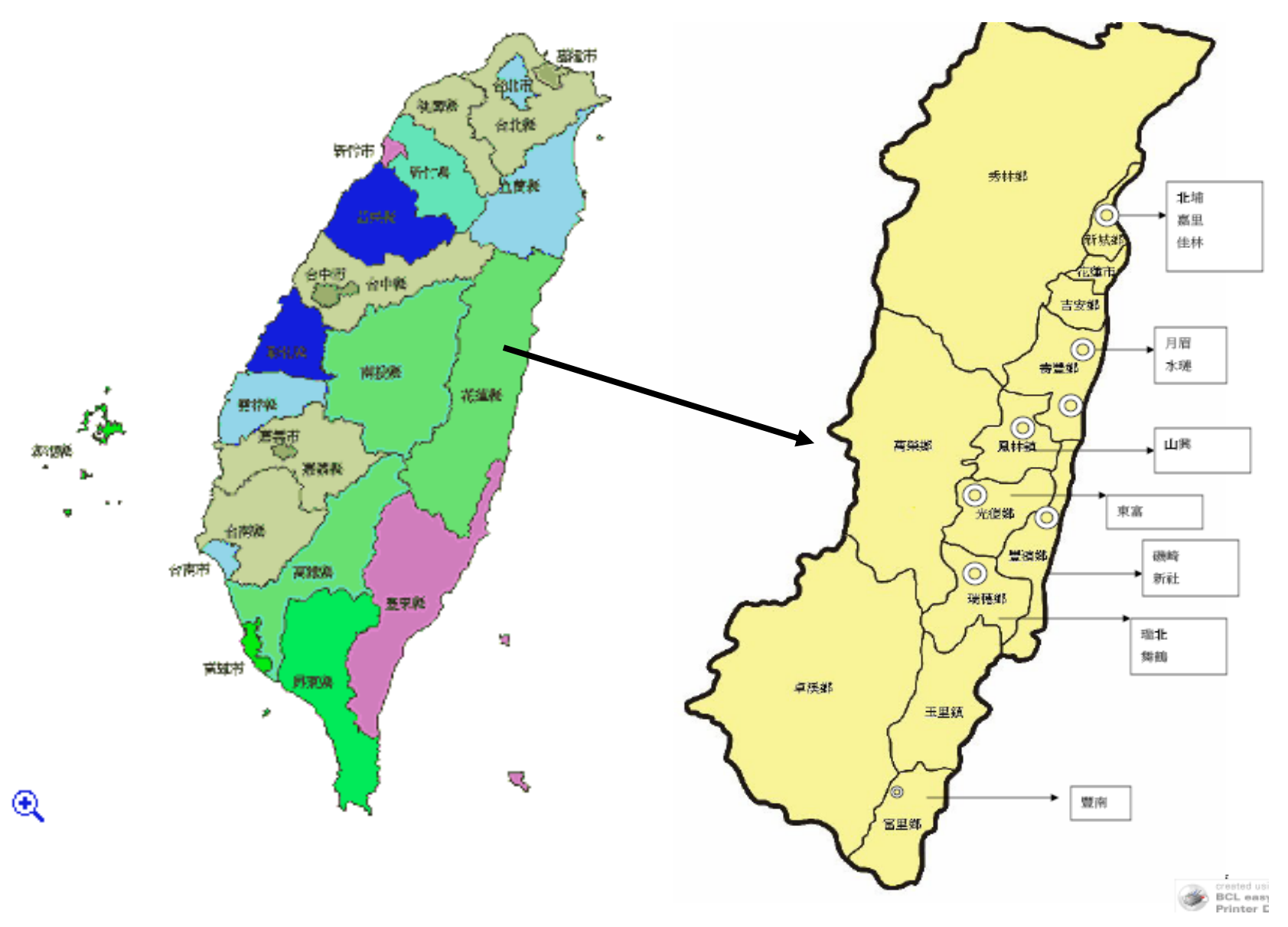

Figure 2. (Lin, 2007) 


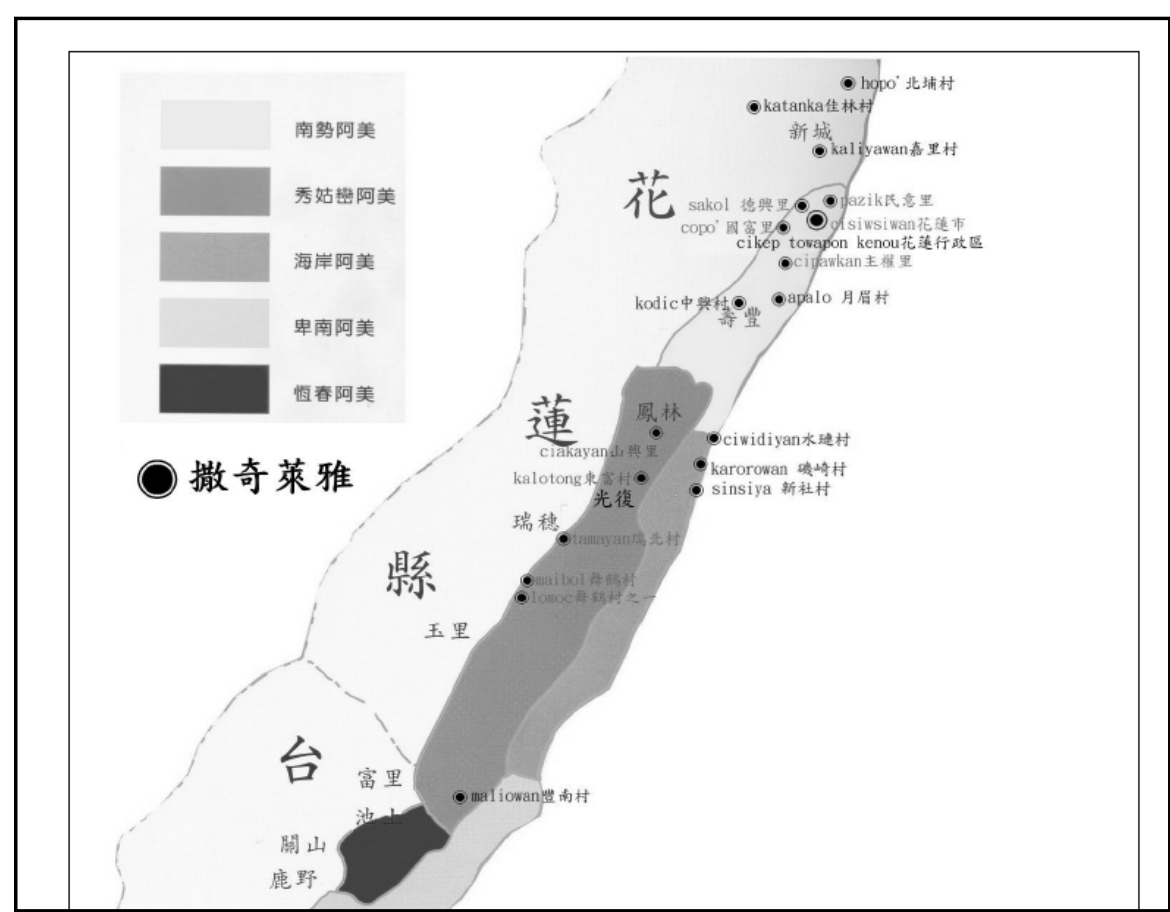

Figure 3. The current distribution of Sakizaya and Amis in Hualien County. (Huang 2005; Lin 2007) 